\title{
Balneotherapy in the Boghiş Resort
}

\section{Gáspár Boróka1, Gabriela Dogaru1,2}

1. Clinical Rehabilitation Hospital Cluj-Napoca

2. "Iuliu Hatieganu" University of Medicine and Pharmacy Cluj-Napoca

\begin{abstract}
The Băile Boghiş resort in Sălaj county is situated in the Barcău depression, at $15 \mathrm{~km}$ distance from Şimleu Silvaniei, in a sedative-indifferent climate of hills, at an altitude of $300 \mathrm{~m}$, without excessive temperatures, with a mean annual rainfall of $650 \mathrm{~mm}$.

The first evidence of the climate and thermal mineral waters of the resort dates back to the 18th century. The Nuşfalău-Boghiş thermal mineral water reservoir is confined to deep permeable aquiferous layers that correspond to the altered zone of crystalline basement and sedimentary formations of Miocene and Pliocene age.

It is an all-season spa and climatic resort; the bicarbonate, sodium, sulfur, iodine hypotonic hyperthermal mineral springs (with a total mineralization of 1016.2-1432.8 $\mathrm{mg} / \mathrm{l}$ ) come from hydrogeological wells, producing over $1900 \mathrm{~m}^{3} /$ day waters with a temperature of $40-42^{\circ} \mathrm{C}$. The spa has 2 outdoor pools (in summer time), bathtubs (in the process of being rehabilitated) and an indoor pool.
\end{abstract} resort.

The peat mud from Stoboru (Cuzăplac commune) is another therapeutic factor used in the

Therapeutic indications are related to the following disorders: osteoarticular system diseases, abarticular and degenerative rheumatic diseases, posttraumatic, peripheral neurological, gynecological, endocrine, nutrition and metabolic disorders, treated by external use (pool or bathtubs), while cooled water is used for crenotherapy.

A specific feature is that thermal water, which has a temperature of $40-42^{\circ} \mathrm{C}$, can be used without being successively cooled or heated in pools or bathtubs, which allows to maintain its initial qualities.

This paper includes early and recent data on a resort that is progressing from a local level to the national circuit, having an important extension potential.

Key words: thermal mineral water, local resort, balneotherapy

The Băile Boghiş spa resort in Sălaj county is situated in the Barcău depression, at $15 \mathrm{~km}$ distance from Şimleu Silvaniei, at an altitude of $300 \mathrm{~m}$, in a sedativeindifferent climate of hills. Compared to the mountain area, climate has softer characteristics regarding temperature, as well as rainfall and air current dynamics. Air temperature is moderate (annual mean value $9.5^{\circ} \mathrm{C}$ ), with moderate rainfall (annual mean value $650 \mathrm{~mm}$ ), with reduced air current dynamics. The annual mean relative humidity is $80 \%$, and north- western and western winds are predominant. Under these conditions, treatment and rest in the resort is recommended to the widest range of patients, young, elderly and children, those who do not tolerate climatic stress (the body will not receive too intense stimuli and will not make great acclimatization efforts), associated with the other natural factors: mineral water, mud[ $1,2,3]$.

Băile Boghiş is an all-season spa and climatic resort; the bicarbonate, sodium, sulfur hypotonic hyperthermal 
mineral springs (with a total mineralization of 1016.2-1432.8 $\mathrm{mg} / \mathrm{l})$ come from hydrogeological wells, producing over $1900 \mathrm{~m}^{3} /$ day waters with a temperature of $40-42^{\circ} \mathrm{C}$. The thermal mineral water sources are represented by 3 wellbores, and there are 2 outdoor pools (in summer time), bathtubs (in the process of being rehabilitated) and an indoor pool[1,2,3]

The peat mud from Stoboru (Cuzăplac commune) is another therapeutic factor used in the resort.

The first evidence of the climate and thermal mineral waters of the resort, situated between the Plopis hills and the Sylvania Piedmont, dates back to the 18th century. The Nuşfalău-Boghiş thermal mineral water reservoir is confined to deep permeable aquiferous layers that correspond to the altered zone of crystalline basement and sedimentary formations of Miocene and Pliocene age.

The hydrogeological characteristics of the mineral water reservoir were investigated through explorationexploitation drilling. In 1971, for the first time, drilling led to the discovery of mineral waters, $400 \mathrm{~m}$ west of Boghiş. The therapeutic mineral water discovered had a temperature of 41 degrees Celsius.

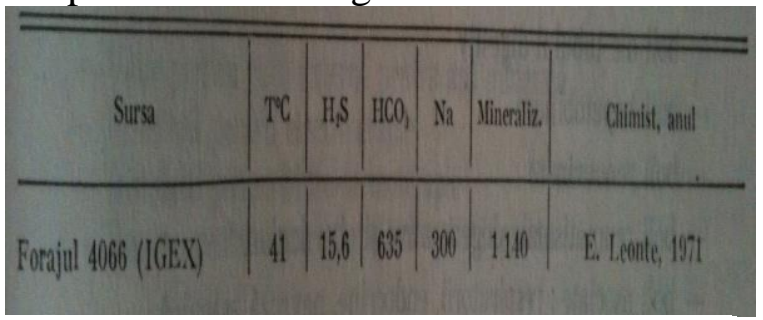

Table 1 - Physico-chemical specificity of mineral water in Boghiş ${ }^{1}$

In summer, local people had therapeutic baths in bathtubs near the wellbore. At the end of 1971, a 20x30 m outdoor pool was built. Since then, Boghiş has been an all-season resort; in winter, the thermality and composition of the water were maintained by covering the pool with a protective foil.

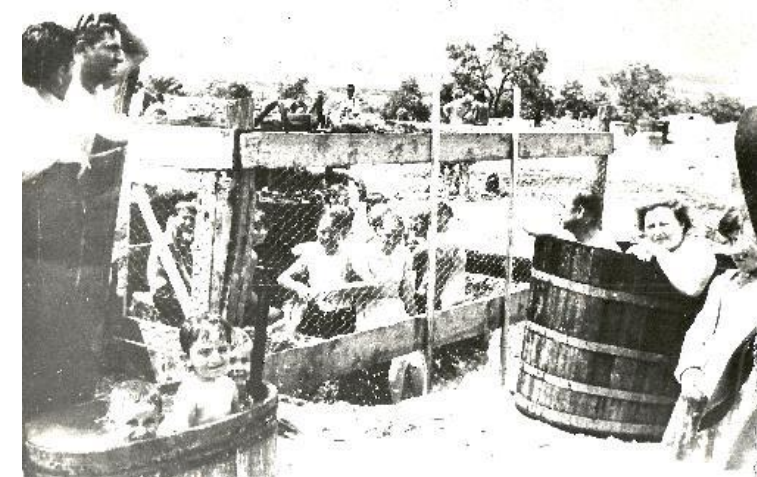

Fig. 1 - The first beneficiaries of spa treatment in the summer of $1971^{2}$

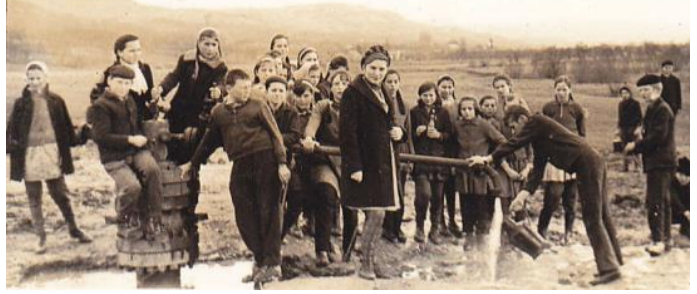

Fig. 2 - Students on a trip at the Boghiş wellbore, $1971^{3}$

The second period of development of the resort started in 1975, with the construction of two pools, the first for adults, having a $25 \mathrm{~m}$ diameter, and the second for children, with a $50 \mathrm{~m}$ diameter. Around the pools, dressing rooms were built and green spaces and camping areas were created.

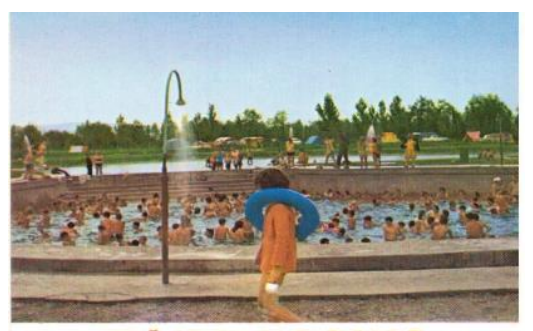

BAILE BOGHIS JuDETUL SALAJ

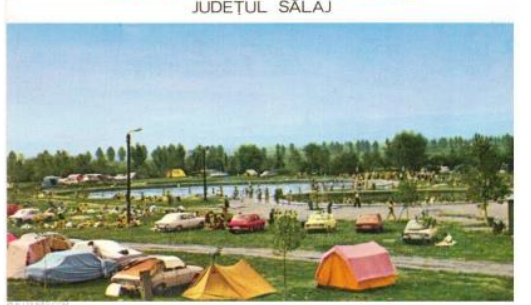

Fig. 3 - The Boghiş resort in 1978 (postcard) 
Wood cabins were built for accommodation, followed by the construction of a restaurant, and in 1976, the construction of a hotel, which had a $20 \times 8 \mathrm{~m}$ indoor pool on the ground floor and rooms upstairs, was finalized. Near the pool, 12 bathrooms with bathtubs were built. Starting with this year, paraffin and mud treatment was administered until $1990[4,5]$.

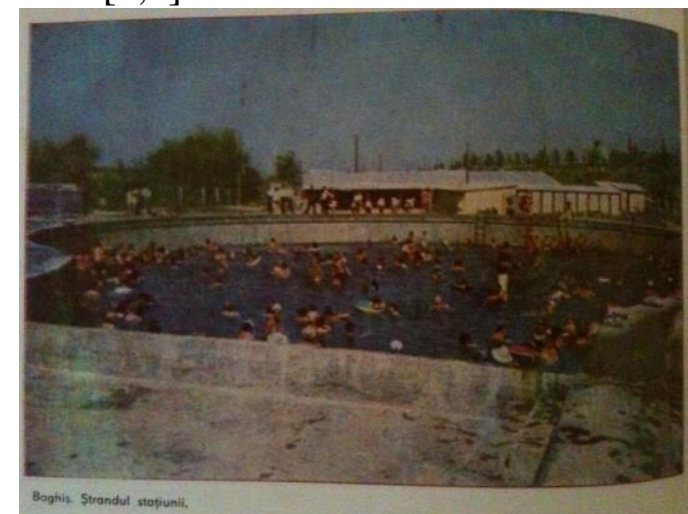

Fig. 4 - The Băile Boghiş resort (in 1984) ${ }^{4}$

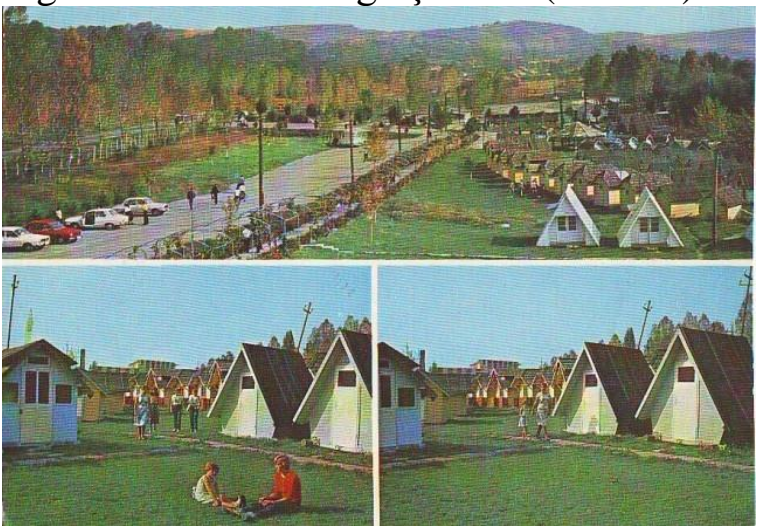

Fig. 5 - View of the resort in 1988 (postcard)

During this period, there were 148 wood cabins (see Fig. 5) and 350 camping places, the resort having a capacity of 1400-1500 persons.

The thermal mineral water sources in the Nuşfălau-Boghiş area are the wells 4066, 4073 and 1851A:

\begin{tabular}{|c|c|c|c|}
\hline $\begin{array}{l}\text { Types of } \\
\text { wells in } \\
\text { Boghiş/ } \\
\text { Characteri } \\
\text { stics }\end{array}$ & $\begin{array}{l}\text { Well } \\
4066 \\
(1971)\end{array}$ & $\begin{array}{l}\text { Well } \\
4073 \\
(1977)\end{array}$ & $\begin{array}{l}\text { Well } \\
\text { 1851A } \\
(1980)\end{array}$ \\
\hline Location & $\begin{array}{l}\text { In the } \\
\text { proximit }\end{array}$ & $\begin{array}{l}800 \\
\text { meters }\end{array}$ & $\begin{array}{l}1125 \\
\text { meters }\end{array}$ \\
\hline
\end{tabular}

\begin{tabular}{|c|c|c|c|}
\hline & $\begin{array}{l}\text { y of the } \\
\text { Nuşfala } \\
\text { u- } \\
\text { Boghis } \\
\text { road, } \\
\text { about } \\
750 \\
\text { meters } \\
\text { downstr } \\
\text { eam of } \\
\text { Boghiş }\end{array}$ & $\begin{array}{l}\text { south of } \\
\text { the well } \\
4066 \text {, in } \\
\text { the } \\
\text { proximit } \\
\text { y of the } \\
\text { Boghiş- } \\
\text { Bozieş } \\
\text { road }\end{array}$ & $\begin{array}{l}\text { north of } \\
\text { the well } \\
4066\end{array}$ \\
\hline Depth & $\begin{array}{l}907 \\
\text { meters }\end{array}$ & $\begin{array}{l}815 \\
\text { meters }\end{array}$ & $\begin{array}{l}916 \\
\text { meters }\end{array}$ \\
\hline $\begin{array}{l}\text { Wellbore } \\
\text { flow }\end{array}$ & $\begin{array}{lr}15 & 1 / \mathrm{sec} \\
- & 11 \\
1 / \mathrm{sec} & \\
(1998)\end{array}$ & $\begin{array}{l}6.50 \\
1 / \mathrm{sec}-4 \\
1 / \mathrm{sec} \\
(1998)\end{array}$ & $\begin{array}{l}7.50 \\
1 / \mathrm{sec}-6 \\
1 / \mathrm{sec} \\
(1998)\end{array}$ \\
\hline $\begin{array}{l}\text { Static } \\
\text { pressure }\end{array}$ & $\begin{array}{l}4.50 \text { at - } \\
3.50 \text { at }\end{array}$ & $\begin{array}{l}3.10 \text { at - } \\
2.80 \text { at }\end{array}$ & 3.10 at \\
\hline $\begin{array}{l}\text { Water } \\
\text { temperatu } \\
\text { re }\end{array}$ & $\begin{array}{l}\text { between } \\
+41^{\circ} \mathrm{C} \\
\text { and } \\
42^{\circ} \mathrm{C}\end{array}$ & $\begin{array}{l}\text { between } \\
+40^{\circ} \mathrm{C} \\
\text { and } \\
41^{\circ} \mathrm{C}\end{array}$ & $\begin{array}{l}\text { between } \\
+41^{\circ} \mathrm{C} \\
\text { and } \\
42^{\circ} \mathrm{C}\end{array}$ \\
\hline $\begin{array}{l}\text { Total } \\
\text { mineraliza } \\
\text { tion }\end{array}$ & $\begin{array}{l}\text { bicarbon } \\
\text { ate, } \\
\text { sodium: } \\
1042.50 \\
-\quad 1140 \\
\mathrm{mg} / \mathrm{l}\end{array}$ & $\begin{array}{l}\text { bicarbo } \\
\text { nate, } \\
\text { sodium, } \\
\text { iodine: } \\
\text { 1016.20 } \\
\mathrm{mg} / \mathrm{l}\end{array}$ & $\begin{array}{l}\text { bicarbo } \\
\text { nate, } \\
\text { sodium, } \\
\text { iodine: } \\
\text { 1432.8 } \\
\mathrm{mg} / \mathrm{l}\end{array}$ \\
\hline
\end{tabular}

Table 2 - Measurements performed in the hydrogeological wells in the period 1971$1998^{5}$

Studies have shown the immunomodulatory action of mineral waters. Thermal water contributes to cell membrane fluidization, reduces lipid peroxidation, inflammatory cell chemotaxis, inhibits the proliferation of lymphocytes induced by epidermal dendritic cells (Langerhans cells). These dendritic cells exert their effect on antigen transport through the lymphatic system, being a lymph node "cluster" for $\mathrm{T}$ naive cells. The inhibitory effect of thermal mineral waters in the expression of vascular endothelial growth factor A, tumor necrosis factor-induced E-selectin and some adhesion cell molecules, as well as the inhibition of inflammatory cytokines 
interleukin-6, -8, -1 $\alpha$, which can be therapeutic targets in psoriasis, for example, have been demonstrated.

Sulfur has an antibacterial, antifungal, antiinflammatory and keratolytic action, it inhibits $\mathrm{T}$ lymphocyte proliferation, the development of $\mathrm{T}$ helper subsets (Th1 cells have been associated with autoimmune diseases and psoriasis, Th2 cells with bronchial asthma and atopic dermatitis, and Th17 cells have been related to the body's defense against bacterial, fungal infections and to the induction of atopic dermatitis and skin lesions in psoriasis) [6,7].

Sulfur water baths raise the pain threshold due to the transport of calcium from the deep layers to the surface of the epidermis, they increase the sensitivity of heat receptors and reduce sensitivity to cold. Thermal sulfur baths induce cutaneous vasodilation and the release of chemical mediators (acetylcholine, prostaglandin, histamine). As a result of blood circulation activation, keratolytic and desensitizing effects, vegetative tone rebalancing, sulfur mineral water has therapeutic indications in skin diseases (allergodermia, pruriginous dermatosis, eczema), along with major indications in chronic (degenerative and inflammatory) rheumatic diseases (at early stages/in remission)[6]. Mineral waters with chemical elements similar to those in Boghiş have beneficial effects in patients with neurasthenia, such as the improvement of perception, attention and memory indices, they normalize the lipid metabolism index and cardiac hemodynamic parameters, as well as renal function through the elimination of adrenaline and noradrenaline, 17ketosteroids and 17-oxycorticosteroids[6].

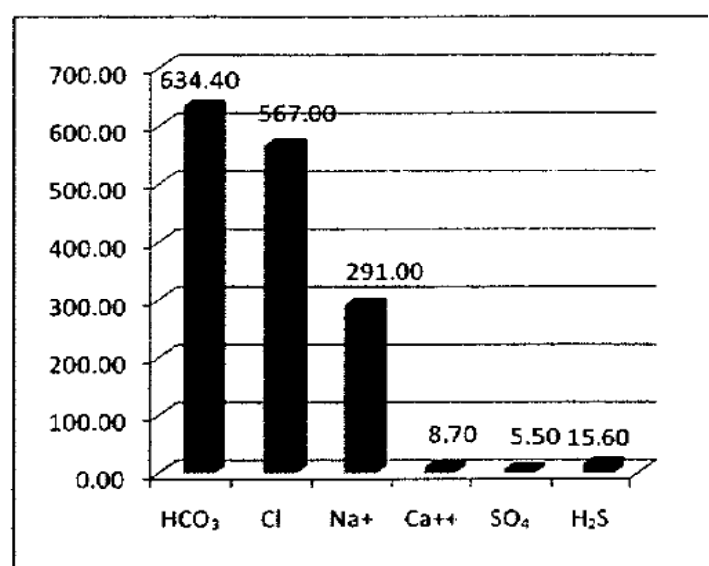

Fig. 6 - Chemical composition (mg/l) of thermal water in the Boghiş resort, $2005^{6}$

According to research performed in 2005 by the Institute of Balneology and Physiotherapy in Bucharest, thermal water in Boghiş contains $634.4 \mathrm{mg} / \mathrm{l}$ bicarbonate, $567 \mathrm{mg} / \mathrm{l}$ chlorine, $291 \mathrm{mg} / \mathrm{l}$ sodium, 5.5 $\mathrm{mg} / \mathrm{l}$ sulfur[7].

Spa treatment indications should take into consideration the patient's general status, nutritional status, muscle strength, the form and stage of the disease, which must be determined by clinical, anatomical and functional diagnosis, along with laboratory and imaging examinations.

Therapeutic indications concern the following disorders:

*Locomotor system diseases:

- degenerative rheumatic diseases - cervical, dorsal and lumbar spondylosis, arthrosis and polyarthrosis

- abarticular rheumatic diseases - tendomyosis, scapulohumeral periarthritis

*Peripheral neurological diseases - mild paresis and minor sequelae after polyneuropathies and poliomyelitis

*Posttraumatic disorders - posttraumatic joint stiffness, conditions following muscle, joint and bone surgery, conditions after sprains, dislocations and fractures *Gynecological diseases - ovarian failure, chronic cervicitis

*Endocrinological, dermatological disorders, nutrition and metabolic diseases[7]. 
Mineral water is used externally (in pools or bathtubs), and cooled water is used for crenotherapy.

The general contraindications of spa treatment are:

*acute, febrile disorders, chronic disorders with exacerbation periods

*infectious or venereal diseases, during contagious periods

*carriers of pathogens or parasitic infestations

* cachectic states

*malignant tumors, regardless of form, site or evolution stage

*repeated and abundant hemorrhage of any nature

*hematologic diseases

*pathological pregnancy or normal pregnancy over 3 months

*epilepsy, decompensated mental disorders *toxicomania, chronic alcoholism with neuropsychiatric disorders

*potentially contagious skin diseases

*manifest cardiovascular, respiratory, renal or liver failure

*patients incapable of self-care (they will be sent to special sanatoriums/with an assistant)[7].

For therapeutic purposes, the peat mud from Stoboru with an acid $\mathrm{pH}(1-2)$, resulting from the oxidation of pyrites penetrating the deposit situated below a 1.5 $m$ thick clay layer, eroded by the Bârcu stream, has been used in the resort. Classified as one of the highest iron content muds worldwide (according to analyses of the Institute of Geology in Vienna), this mud was used for spa purposes as early as 1881 . It consists of $69.28 \%$ iron vitriol (FeSO4+7 $\mathrm{H} 2 \mathrm{O}$ ), with a $0.54 \% \mathrm{H} 2 \mathrm{SO} 4$ residue[7].

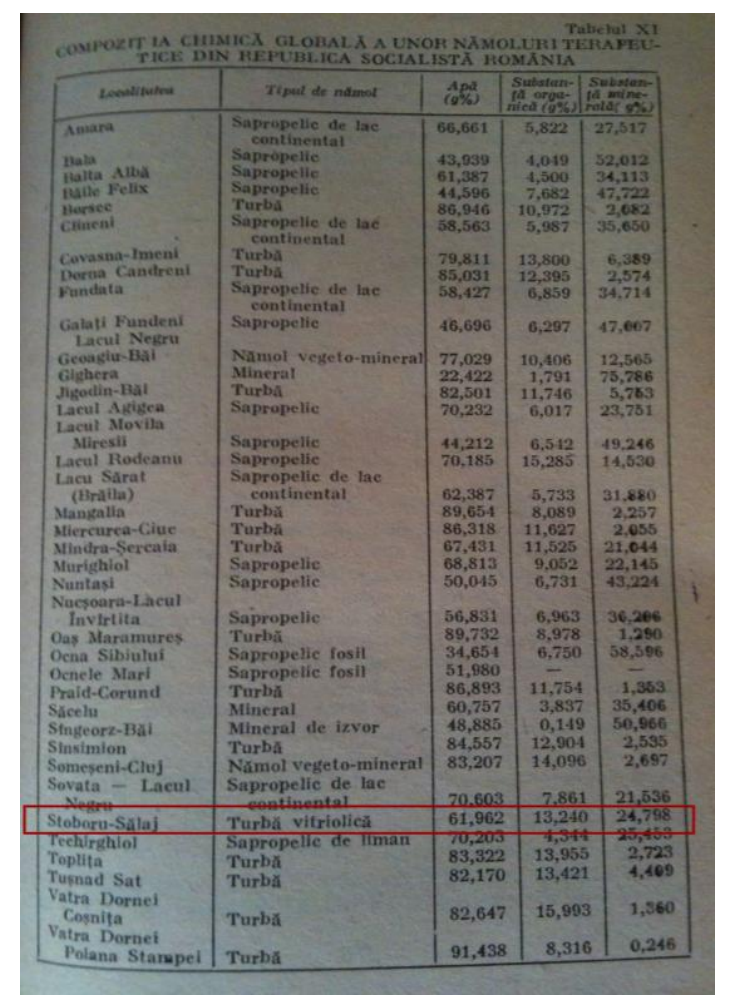

Table 3 - Chemical composition of therapeutic mud used in the Boghiş resort ${ }^{7}$

A specific feature of thermal water, which has a temperature of $40-42^{\circ} \mathrm{C}$, is that it can be used in leisure pools or bathtubs without being successively cooled or heated, which allows to maintain its initial properties.

This paper includes early and recent data on a resort that is progressing from a local level to the national circuit, having an important extension potential.

\section{BIBLIOGRAPHY}

\footnotetext{
${ }^{1}$ Cura balneo-climatică. Indicaţii şi contraindicaţii. Editura Medicală, Craiova, 1986, pp. 269

${ }^{2}$ www.webvidek.ro

${ }^{3}$ www.szilagybagos.ro

4 N. Teleki, L. Munteanau et al. Cura balneoclimatică în România. Ed. Sport Turism, Bucureşti, 1984

5 Monografie Turistică Baile Boghiş, www. răsfoiesc.com

${ }^{6}$ B. Simon Gy, L Tőtős. Boghiş la 800 de ani monografie. Zalău, 2005, p. 21

7 L. Munteanu, C. Stoicescu, L. Grigore. Ghidul staţiunilor balneoclimatice din România. Ed. Sport Turism, 1986, p. 75
} 